\title{
Maitorasva ja terveys
}

\author{
Anu Turpeinen ${ }^{1)}$ ja Marja Mutanen ${ }^{1)}$ \\ ${ }^{1)}$ Helsingin yliopisto, Soveltavan kemian ja mikrobiologian laitos, ravitsemustiede, PL66, 00014 \\ Helsingin yliopisto, marja.mutanen@helsinki.fi
}

Maitorasvasta on löydetty yli 400 rasvahappoa, joten sitä voidaan hyvällä syyllä kutsua monipuoliseksi rasvaksi. Maitorasvassa on useita potentiaalisia terveysvaikutuksia omaavia komponentteja, eikä jako terveydelle edullisiin tai haitallisiin rasvahappoihin ole yksiselitteinen.

Sekä yksittäisten tyydyttyneiden rasvahappojen että maitorasvan vaikutuksia veren rasvaarvoihin ja sydän- ja verisuonitautirikiin on tutkittu runsaasti. Lyhyt- ja keskipitkäketjuiset tyydyttyneet rasvahapot (4:0, 6:0, 8:0 ja 10:0) ja steariinihappo (18:0) eivät vaikuta seerumin kolesterolitasoon. Kolesterolia nostavia tyydyttyneitä rasvahappoja ovat myristiinihappo (C14:0), palmitiinihappo (C16:0) ja lauriinihappo (C12:0). Korvattaessa ruokavalion maitorasva kasviöljyillä kokonaiskolesteroli ja LDL-kolesteroli pääsääntöisesti laskevat. Useissa seurantatutkimuksissa on todettu yhteys tyydyttyneen rasvan saannin, LDL-kolesterolin ja sydän- ja verisuonitautien esiintyvyyden välillä, sekä miehillä että naisilla.

Maitorasvassa on komponentteja, joilla on in vitro ja eläinkokeissa todettu antikarsinogeenisia vaikutuksia. Tutkimustulokset runsaan maitorasvan saannin ja toisaalta maitotuotteiden kulutuksen yhteyksistä yleisimpien syöpien esiintyvyyteen ovat ristiriitaisia. Kahdessa suomalaisessa väestötutkimuksessa on todettu käänteinen yhteys meijerituotteiden käytön ja rintasyöpäriskin välillä. Laajassa ruotsalaisessa tutkimuksessa runsas maitotuotteiden käyttö vähensi paksu- ja peräsuolisyövän riskiä naisilla. Tuoreen World Cancer Research Fundin raportin mukaan tutkimusnäyttö viittaa siihen, että runsas maitotuotteiden käyttö vähentää paksu- ja peräsuolisyövän riskiä. Rintasyövän osalta muualla maailmassa tehdyissä tutkimuksissa ei ole saatu vahvistusta suomalaishavainnoille. Toisaalta runsas kalsiumin saanti todennäköisesti lisää eturauhassyövän riskiä. Maitotuotteissa saattaakin olla sekä syövältä suojaavia että syövälle altistavia tekijöitä.

Viime vuosina on julkaistu useita tutkimuksia, joissa maitotuotteiden kulutuksella on ollut edullisia vaikutuksia metabolisen oireyhtymän ja 2 tyypin diabeteksen esiintyvyyteen ja riskitekijöihin. Toteutimme HY:n ravitsemustieteen osastolla pohjoismaisena yhteistyöprojektina tutkimuksen, jossa selvitettiin runsaan maitotuotteiden käytön vaikutuksia metabolisen oireyhtymän riskitekijöihin. Tutkittavat nauttivat päivittäin 3-5 annosta maitotuotteita puolen vuoden ajan, kontrolliryhmän jatkaessa vähän maitotuotteita sisältäneen ruokavalion nauttimista.

Maidossa on lukuisia terveysvaikutuksia omaavia komponentteja ja maitotuotteiden runsas kulutus on yhteydessä useisiin edullisiin terveysvaikutuksiin. On kuitenkin yhä suurelta osin epäselvää, onko kyseessä yhden tekijän vaikutus vai useiden tekijöiden yhteisvaikutus ja missä fraktiossa (rasva vs. ei-rasva) maidon hyödylliset ominaisuudet sijaitsevat. Läheskään kaikkien potentiaalisten komponenttien vaikutuksia ei ole vielä tutkittu ihmisillä.

Asiasanat: maitorasva, maitotuotteet, sydän- ja verisuonitaudit, syöpä, metabolinen oireyhtymä 


\section{Johdanto}

Maitorasvan neljästäsadasta rasvahaposta suurin osa (n. 60\%) on tyydyttyneitä, 4-18 hiiltä sisältäviä rasvahappoja. Maitorasva sisältää myös melko runsaasti kertatyydyttymättömiä rasvahappoja (n. $20 \%$ ), mutta vähän monityydyttymättömiä rasvahappoja (2-3\%). Transrasvahappoja on keskimäärin 24\% kokonaisrasvasta. Myös muilla maitorasvan komponenteilla saattaa olla terveysvaikutuksia. Tässä katsauksessa käsitellään maitorasvan ja sen eräiden komponenttien yhteyksiä sydän ja verisuonitautien, syövän ja metabolisen oireyhtymän riskitekijöihin ja esiintyvyyteen.

\section{Maitorasva ja seerumin kolesterolitaso}

Lyhyt- ja keskipitkäketjuiset tyydyttyneet rasvahapot (4:0, 6:0, 8:0 ja 10:0) sekä steariinihappo (18:0), eivät vaikuta seerumin kolesterolitasoon. Kolesterolia nostavia tyydyttyneitä rasvahappoja ovat lauriinihappo (C12:0), myristiinihappo (C14:0) ja palmitiinihappo (C16:0), jotka muodostavat 35$50 \%$ maitorasvan rasvahapoista. Käsitykset siitä, mikä näistä rasvahapoista nostaa eniten kolesterolia on vaihdellut, koska kyseiset rasvahapot esiintyvät rasvoissa yleensä yhdessä ja niiden vaikutusten tutkiminen erikseen on hankalaa. Viime vuosien aikana tutkimuksissa on jo voitu käyttää yksittäistä tyydyttynyttä rasvahappoa sisältäviä rasvoja ja tämänhetkisen käsityksen mukaan lauriinihappo nostaa eniten kokonaiskolesterolia (Mensink ym. 2003). Myristiini-, palmitiini- ja lauriinihappo nostavat kaikki LDL-kolesterolia vähentämällä maksan LDL-reseptoreiden aktiivisuutta, minkä seurauksena LDL:n määrä veressä lisääntyy (Salter ym. 1998).

Myös eräillä kertatyydyttymättömillä transrasvahapoilla on epäedullisia vaikutuksia veren rasva-arvoihin, niiden nostaessa kokonais- ja LDL-kolesterolia ja laskiessa HDL-kolesterolia (Ascherio 2006). Maitorasvan transrasvahapoista suurin osa on kertatyydyttymättömiä C18rasvahappoja. Isomeerikoostumukseltaan ne ovat kuitenkin erilaisia kuin kasviöljyjen osittaisessa kemiallisessa kovettamisessa muodotuvat transrasvahapot, joilla epäedullisia vaikutuksia on todettu. Tutkimuksia, joissa verrattaisiin kovetetun kasvirasvan ja maitorasvan transrasvahappojen terveysvaikutuksia ihmisillä ei ole julkaistu ja on epäselvää, ovatko myös maitorasvan transrasvahappojen vaikutukset epäedullisia. Maitorasva sisältää myös pieniä määriä monityydyttymätöntä transrasvahappoa, konjugoitunutta linolihappoa (CLA). Kaneilla ja hamstereilla CLA on laskenut kokonais- ja LDL-kolesterolia, hidastanut rasvajuosteiden kertymistä verisuoniin ja jopa pienentänyt olemassaolevia rasvajuosteita. CLA:n vaikutuksia verisuonimuutoksiin ei ole tutkittu ihmisillä, mutta veren rasva-arvoihin ei ole todettu merkittäviä vaikutuksia terveillä tai hyperlipidemisillä henkilöillä (Tricon ym. 2005).

Interventiotutkimuksissa on verrattu maitorasvan, kasviöljyjen ja hiilihydraattien vaikutuksia veren rasva-arvoihin. Korvattaessa maitorasva hiilihydraateilla tai runsaasti kerta- tai monityydyttymättömiä rasvahappoja sisältävillä kasviöljyillä, seerumin kokonaiskolesteroli ja LDLkolesteroli laskevat (Mensink 2003). Myös HDL-kolesteroli laskee, mutta edellämainittuja vähemmän, jolloin kokonaisvaikutus on edullinen. Hiilihydraatit nostavat seerumin triglyseriditasoa maitorasvaan verrattuna, sen sijaan maitorasvan ja kasviöljyjen vaikutuksissa ei ole merkittävää eroa. Kuvassa 1 on esitetty muutokset seerumin kokonais-, LDL- ja HDL-kolesterolissa, kun ruokavalion rasvan laatu muutetaan. Vertailukohtana on keskimääräinen länsimainen ruokavalio.

\section{Tyydyttynyt rasva, seerumin kolesteroli ja sydän- ja verisuonitaudit}

Useissa laajoissa prospektiivisissa seurantatutkimuksissa on todettu yhteys seerumin kolesterolitason ja sydän- ja verisuonitautiriskin välillä kaikenikäisillä naisilla ja miehillä (Stamler ym. 1986, Levine ym. 1995). Vastaavasti kolesterolitason laskeminen lääkkeiden avulla laskee sydän- ja verisuonitautiriskiä (Levine ym. 1995). Miehillä LDL-kolesterolin yhteys sydäntautiriskiin on voimakkaampi kuin naisilla. Ns. Seitsemän maan tutkimuksen 25-vuotisseurannassa (Kromhout ym. 1995) seerumin kolesteroli korreloi sydäntautikuolleisuuden kanssa kaikissa maissa. Kuolleisuus sydäntauteihin kuitenkin vaihteli huomattavasti maiden välillä. Kolesterolitasolla $5.2 \mathrm{mmol} / \mathrm{L}$ kuolleisuus Pohjois-Euroopassa oli viisinkertainen Japaniin verrattuna. Erot kuolleisuudessa säilyivät iällä, tupakoinnilla ja verenpaineella vakioinnin jälkeen. Havainto viittaa siihen, että länsimaissa myös muiden riskitekijöiden vaikutus on merkittävä. 
Runsas tyydyttyneen rasvan saanti on myös ollut yhteydessä sydäntauteihin useissa tutkimuksissa (kts. Xu ym. 2006). Kaikissa tutkimuksissa yhteyttä tyydyttyneen rasvan saannin ja sydäntautiriskin välillä ei ole todettu (Shekelle ym. 1981, Pietinen ym. 1997, Ascherio ym. 1996) ja tyydyttyneillä rasvahapoilla on jopa esitetty olevan suojaava vaikutus ateroskleroosin etenemiseen (Mozaffarian ym. 2004). Ravinnon rasvan kokonaissaanti ja rasvahappokoostumus, tutkittavan terveydentila ja sukupuoli muiden muassa vaikuttavat siihen, todetaanko yhteys ja kuinka voimakas se on. Mm. metabolista oireyhtymää sairastavilla henkilöillä, joilla HDL-taso on tyypillisesti alhainen ja seerumin triglyseriditaso koholla, hiilihydraattien korvaaminen tyydyttyneellä rasvalla voi johtaa edullisiin muutoksiin rasva-arvoissa. Mikäli näitä taustatekijöitä ei otetan huomioon, voidaan päätyä ristiriitaisiin johtopäätöksiin.

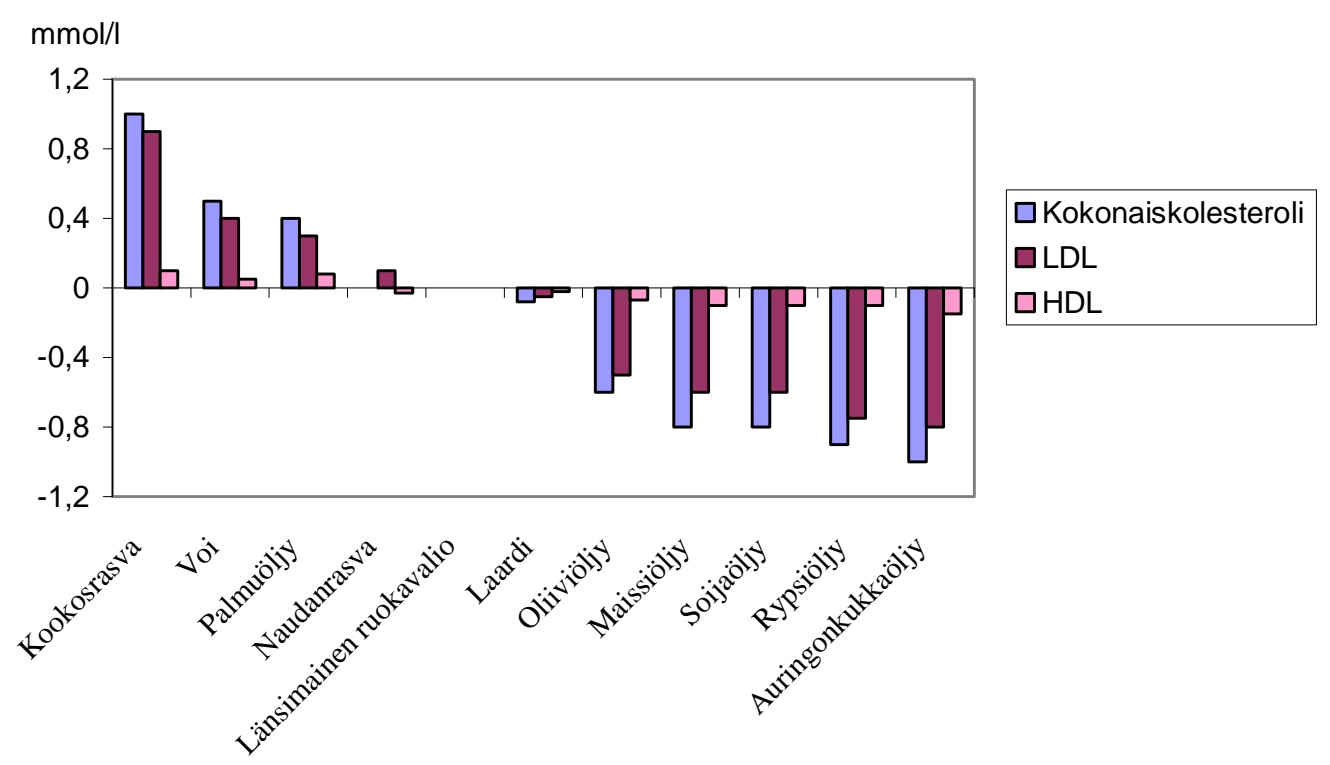

Kuva 1. Muutokset seerumin kokonais-, LDL- ja HDL-kolesterolissa keskimääräiseen länsimäiseen ruokavalioon nähden, kun ruokavalion rasvan laatu muutetaan (Mensink ym. 2003, Katan ym. 1995).

\section{Maitorasva ja syöpä}

Tutkimustulokset runsaan maitorasvan saannin ja maitotuotteiden kulutuksen yhteyksistä yleisimpien syöpien esiintyvyyteen ovat ristiriitaisia. Tuoreen World Cancer Research Fundin raportin (www.wcrf.org) mukaan tutkimusnäyttö viittaa siihen, että runsas maitotuotteiden kulutus suojaa paksu- ja peräsuolisyövältä. Toisaalta runsas kalsiumin saanti lisää todennäköisesti eturauhassyövän riskiä. Maito saattaa sisältää sekä syövältä suojaavia tekijöitä, että syövälle altistavia tekijöitä. Eräillä maitorasvan komponenteilla - CLA:lla (Ip ym. 1994), sfingolipideillä (Merrill ym. 1995) ja voihapolla (German 1999) - on todettu antikarsinogeenisia ominaisuuksia. Seuraavissa kappaleissa käsitellään kunkin komponentin osalta tämänhetkistä tutkimusnäyttöä.

\section{Konjugoitu linolihappo}

Konjugoidun linolihapon antikarsinogeenisia vaikutuksia on tutkittu runsaasti in vitro ja eläinkokeissa. CLA:n on todettu ehkäisevän niin syövän syntyä, etenemistä kuin etäpesäkkeiden muodostusta (kts. Belury ym. 2002). Cis-9, trans-11 CLA-isomeerilla, joka muodostaa pääosan maitotuotteiden CLA:sta, on rotilla todettu edullisia vaikutuksia rinta-, iho- ja eturauhassyövän kehittymiseen ja etenemiseen (kts. Belury 2002). Cis-9, trans-11 CLA vähentää rintasyöpäkasvaimia rotilla annosvasteisesti jo pienillä saantitasoilla (dieetissä 0.05-0.5\% CLA:a) (Ip ym. 1991). CLA:n vaikutus on voimakkain, kun saanti alkaa jo rintakudoksen kehittyessä (Ip ym. 1995).

Laajassa ruotsalaisessa seurantatutkimuksessa 45000 miehellä runsas maitotuotteiden käyttö vähensi paksu- ja peräsuolisyövän riskiä (Larsson ym. 2005). Erityisesti maidon juonti oli yhteydessä pienenpään syöpäriskiin. Tutkijat pitivät mahdollisina vaikuttavina tekijöinä CLA:a, sfingolipidejä 
ja/tai maidon proteiineja (esim. laktoferriini). Kahdessa suomalaisessa väestötutkimuksessa, Autoklinikkatutkimuksessa ja Kuopion rintasyöpätutkimuksessa (Knekt ym 1996, Aro ym. 2000) on todettu käänteinen yhteys meijerituotteiden käytön ja rintasyöpäriskin välillä. Autoklinikkatutkimuksessa maidon juonti liittyi pienentyneeseen syöpäriskiin, Kuopion rintasyöpätutkimuksessa juuston kulutus oli syöpäpotilailla $30 \%$ pienempää kuin verrokeilla. Kuopion rintasyöpätutkimuksessa postmenopausaalisilla naisilla todettiin käänteinen yhteys ravinnon CLA:n ja rintasyöpäriskin välillä. Yhteys näkyi myös seerumin rasvahapoissa: CLA:n ja vakseenihapon (maidon päätransrasvahappo) pitoisuus seerumissa oli rintasyöpäpotilailla merkitsevästi pienempi kuin verrokeilla (Aro ym. 2000). Muualla maailmassa tehdyissä tutkimuksissa ei kuitenkaan ole saatu vahvistusta suomalaishavainnoille (Chajes ym. 2002, Voorrips ym. 2000).

CLA:n vaikutukset ovat isomeerispesifisiä. Omissa tutkimuksissamme paksusuolisyövän hiirimallissa trans-10, cis-12 CLA-isomeeriä syöneillä hiirillä suolikasvaimet olivat suurempia kuin kontrollihiirillä (Rajakangas ym. 2003). Cis-9, trans-11 CLA-isomeeri ei vaikuttanut kasvainten kokoon.

\section{Sfingolipidit}

Sfingolipidit toimivat rakenteen ylläpitäjänä solukalvoilla ja niiden aineenvaihduntatuotteilla, keramidilla ja sfingosiinilla on merkitystä solun viestin välityksessä (signal transduction) ja solun kasvun, erilaistumisen ja ohjelmoidun solukuoleman (apoptoosin) säätelyssä. Sfingolipidit vähentävät solujen jakaantumista useissa eri syöpäsolulinjoissa, joten niillä saattaa olla merkitystä kasvainten muodostumisessa (kts. Vesper ym. 1999). Eniten on tutkittu sfingolipidien yhteyttä paksusuolisyöpään. Hiirillä maidon sfingomyeliiniä sisältänyt ruokavalio vähensi spontaaneja ja kemiallisesti indusoituja paksusuolen kasvaimia kontrolleihin verrattuna (Dillehay ym. 1994). Kasvaimista oli myös suurempi osuus hyvälaatuisia. Vaikutuksia todettiin annostasoilla, jotka ovat lähellä sfingolipidien arvioitua saantia ihmisillä. Ihmisen paksusuolisyövän eläinmallina käytetyllä Min-hiirellä sfingolipidien lisääminen ruokavalioon vähensi kasvainten määrää suolessa (Vesper ym. 1999). Paksu- ja peräsuolisyöpäpotilailla on todettu alentunut sfingomyelinaasientsyymin aktiivisuus suolen kasvaimissa (Hertervig ym. 1997), mutta kokeellisia tutkimuksia sfingolipidien ja paksusuolisyövän yhteyksistä ihmisillä ei ole tehty.

\section{Voihappo}

Voihappo (butyyrihappo, C4:0) muodostaa 2-5 paino-\% kokonaisrasvahapoista maitorasvassa. Sitä muodostuu myös paksusuolessa fermentaatiotuotteena imeytymättömän ravintokuidun hajotessa bakteeritoiminnan tuloksena. Paksusuolen solut käyttävät voihappoa energianlähteenään, mutta osa imeytyneestä voihaposta päätyy maksan porttilaskimoon. Kuidun paksusuolen syöpää ehkäisevän vaikutusten uskotaan välittyvän osittain voihapon kautta. In vitro voihappo mm. lisää apoptoosia (ohjelmoitua solukuolemaa), vähentää solujen proliferaatiota, inaktivoi onkogeenejä ja mahdollisesti estää etäpesäkkeiden muodostumista (kts. German 1999).

Maitorasvan voihappo imeytyy lähes kokonaan ohutsuolesta hydrolysoimattomana suoraan porttilaskimon kautta maksaan, eikä näinollen kulkeudu paksusuoleen asti. Maitorasvan merkitystä voihapon lähteenä ja sen yhteyksiä syöpiin on tutkittu tähän mennessä lähinnä rintasyövän osalta rotilla. Rotilla natriumbutyraatti estää sekä normaalien että rintasyöpäsolujen jakautumista ja lisää apoptoosia (Planchon ym. 1991). Voidieettiä nauttineilla eläimillä oli vähemmän kemiallisesti indusoituja rintakasvaimia kuin margariinidieetillä (Yanagi ym. 1994). Natriumbutyraatin lisääminen margariiniruokavalioon esti kasvainten lisääntymisen annos-vasteisesti (1\% voihappoa vähensi kasvaimia 20\% ja 3\% voihappoa vähensi kasvaimia 52\%) (Belobrajdic \& McIntosh 2000). Ihmisillä ei ole tehty tutkimuksia voihapon mahdollisista vaikutuksista.

\section{Metabolinen oireyhtymä}

Ylipainon lisääntyessä kaikkialla maailmassa myös metabolinen oireyhtymä lisääntyy nopeasti. Viime vuosina on julkaistu useita tutkimuksia, joissa maitotuotteiden kulutuksella on ollut edullisia vaikutuksia metabolisen oireyhtymän ja 2 tyypin diabeteksen esiintyvyyteen ja riskitekijöihin.

Laajassa yhdysvaltalaisessa Health Professionals Follow-up Studyssa yli 40000 osallistujalla 12 vuoden seurannan aikana maitotuotteiden käyttö oli yhteydessä pienempään tyypin 2 diabeteksen riskiin (Choi ym. 2005). Myös prospektiivisessa Cardia-tutkimuksessa ylipainoisilla, runsaasti 
maitotuotteita käyttävillä nuorilla esiintyi vähemmän metabolista oireyhtymää kuin henkilöillä, jotka eivät käyttäneet säännöllisesti maitotuotteita (Pereira ym. 2002)(Kuva 2). Insuliiniresistenssiä on todettu myös vähemmän miehillä, joilla maitotuotteiden käyttö oli runsasta (Mennen ym. 2000). Eräiden, lähes yksinomaan maitorasvasta saatavien rasvahappojen, kuten pentadekaeenihapon (15:0) ja heptadekaeenihapon (17:0), pitoisuudet ovat useissa tutkimuksissa olleet yhteydessä vähäisempään vatsanympärysrasvan määrän ja metabolisen oireyhtymän riskitekijöihin (Rosell ym. 2004, Warensjö ym. 2004).

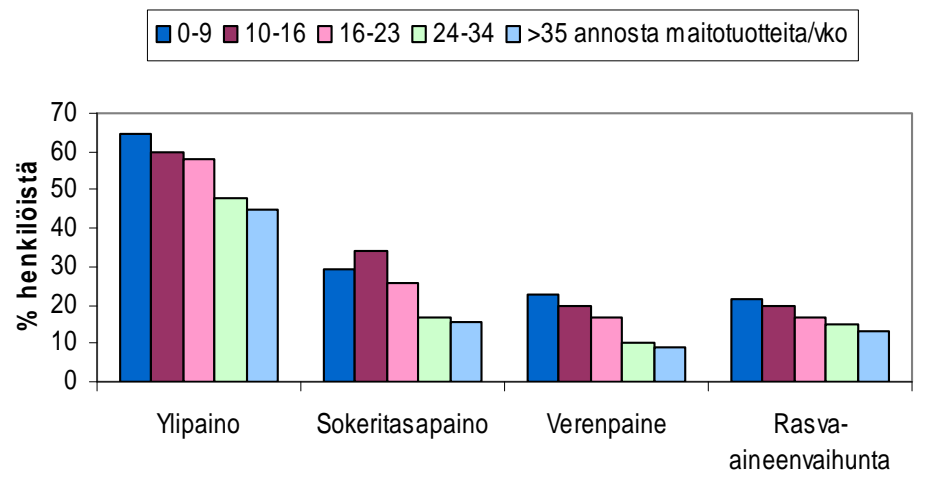

Kuva 2. Eniten maitotuotteita nauttivilla henkilöillä esiintyi vähiten metabolisen oireyhtymän riskitekijöitä Cardia-tutkimuksessa (Pereira ym. 2002)

Ylipaino on tärkein metabolisen oireyhtymän riskitekijöistä. Maitotuotteiden käytöllä on todettu edullisia vaikutuksia painonhallintaan. Väestötutkimuksissa paljon maitovalmisteita käyttävillä henkilöillä ylipaino on ollut huomattavasti vähäisempää kuin vähän maitotuotteita käyttävillä (Zemel ym. 2000). Useissa tutkimuksissa ravinnosta runsaasti kalsiumia saavilla henkilöillä paino, vatsanympärys, painoindeksi ja rasvakudoksen määrä ovat olleet pienempiä kuin vähän kalsiumia saavilla (Davies ym. 2000, Mirmiran ym. 2005). Ylipainoisilla henkilöillä maitotuotteiden lisääminen vähän energiaa sisältävään ruokavalioon paransi laihdutustulosta ja sai aikaan edullisia muutoksia metabolisen oireyhtymän riskitekijöissä (vatsarasvan määrä, glukoosi- ja insuliiniaineenvaihdunta) (Zemel ym. 2004). Maitotuotteiden kulutuksella on todettu myös yhteys alhaisempaan verenpaineeseen (Ruidavets ym. 2006).

Maidon kalsiumin on todettu selittävän osan todetuista vaikutuksista, mutta lähes poikkeuksetta vaikutukset ovat olleet suurempia nautittaessa maitovalmisteita kuin kalsiumtabletteja (Zemel ym. 2004). Maidossa on runsaasti bioaktiivisia komponentteja, joiden kaikkia itsenäisiä vaikutuksia tai yhteisvaikutuksia ei tunneta. Mm. CLA:lla on eläimillä huomattavia vaikutuksia kehon koostumukseen: hiirillä CLA vähensi rasvakudoksen määrää jopa 60\% (Park ym. 1997). Tuoreen meta-analyysin mukaan CLA vähentää kehon rasvan määrää myös ihmisillä (Whigham ym. 2007), mutta vaikutus on melko vähäinen (n. $0.05 \mathrm{~kg} / \mathrm{vko}$ ) ja pitkäaikaisvaikutukset ovat edelleen epäselviä. Tutkimuksissa käytetyt annostasot $(2-6 \mathrm{~g} / \mathrm{pv})$ ovat olleet moninkertaisia verrattuna CLA:n saantiin ravinnosta $(100-400 \mathrm{mg} / \mathrm{pv})$.

Toteutimme pohjoismaisena yhteistyöprojektina tutkimuksen, jossa runsaan maitotuotteiden käytön vaikutuksia metabolisen oireyhtymän riskitekijöihin tutkittiin henkilöillä, joilla oli metabolisen oireyhtymän riskitekijöitä (keskivartalolihavuus, kohonnut verenpaine, häiriöitä rasva- ja sokeriaineenvaihdunnassa). Tutkittavat nauttivat päivittäin 3-5 annosta maitotuotteita puolen vuoden ajan, kontrolliryhmän jatkaessa vähän maitotuotteita sisältäneen ruokavalion nauttimista. Tutkimuksesta saadaan alustavia tuloksia vuoden 2007 loppuun mennessä.

\section{Johtopäätökset}

Maidossa on lukuisia terveysvaikutuksia omaavia komponentteja ja maitotuotteiden runsas kulutus on yhteydessä useisiin edullisiin terveysvaikutuksiin. On kuitenkin yhä suurelta osin epäselvää, onko kyseessä yhden tekijän vaikutus vai useiden tekijöiden yhteisvaikutus ja missä fraktiossa (rasva vs. ei- 
rasva) maidon hyödylliset ominaisuudet sijaitsevat. Läheskään kaikkien potentiaalisten komponenttien vaikutuksia ei ole vielä tutkittu ihmisillä.

Ravitsemussuosituksissa tyydyttyneen rasvan, kuten maitorasvan, saantia suositellaan rajoitettavan, koska runsaasti nautittuna tyydyttynyt rasva lisää seerumin LDL-kolesterolipitoisuutta ja sydän- ja verisuonitautiriskiä. Laaja vähärasvaisten maitotuotteiden valikoima mahdollistaa maitotuotteiden kulutuksen lisäämisen ilman, että maitorasvan saanti nousee liian suureksi.

\section{Kirjallisuus}

Aro, A., Männistö, S., Salminen, I., Ovaskainen, M-L., Kataja, V. \& Uusitupa M. 2000. Inverse association between dietary and serum conjugated linoleic acid and risk of breast cancer in postmenopausal women. Nutr. Cancer 38(2):151-157.

Ascherio, A. 2006. Trans fatty acids and blood lipids. Atherosclerosis Suppl. 7:25-27.

Ascherio, A., Hennekens, C., Willett, W.C., Sacks, F., Rosner, B., Manson, J., Witteman, J. \& Stampfer, M.J. 1996. Prospective study of nutritional factors, blood pressure, and hypertension among US women. Hypertension 27(5):1065-72.

Belobrajdic, D.P. \& McIntosh, G.H. 2000. Dietary butyrate inhibits NMU-induced mammary cancer in rats. Nutr. Cancer 36(2):217-223.

Belury, M.A. 2002. Inhibition of carcinogenesis by conjugated linoleic acid: potential mechanisms of action. J. Nutr. 132:2995-2998.

Chajes, V., Lavillonniere, F., Ferrari, P., Jourdan, M.-L., Pinault, M., Maillard, V., Sebedio, J.-L. \& Bougnoux, P. 2002. Conjugated linoleic acid content in breast adipose tissue is not associated with the relative risk of breast cancer in a population of French patients. Cancer Epidem. Biomarkers Prev. 11:672-673.

Choi, H.K., Willet, W.C., Stampfer, M.J., Rimm, E. \& Hu, F.B. 2005 Dairy consumption and risk of type 2 diabetes mellitus in men - a prospective study. Arch. Intern. Med. 165:997-1003.

German, J.B. Butyric acid: a role in cancer prevention. BNF Nutrition bulletin 1999;24(89):203-209.

Davies, K.M., Heaney, R.P., Recker, R.R., Lappe, J. M., Barger-Lux, M. J. \& Rafferty, K. 2000. Calcium intake and body weight. J. Clin. Endocrinol. Metab. 85:4635-4638.

Dillehay, D.L., Webb, S.J., Schmelz, E.-M. \& Merrill, A.H. 1994. Dietary sphingomyelin inhibits 1,2dimethylhydrazine-induced colon cancer in CF1 mice. J. Nutr. 124:615-620.

German, B. 1999. Butyric acid: a role in cancer protection. B.N.F. Nutrition Bulletin 24:203-209.

Hertevig, E., Nilsson, Å., Nyberg, L. \& Duan, R.D. 1997. Alkaline sphingomyelinase activity is decreased in human colorectal carcinoma. Cancer 79:448-453.

Ip, C., Chin, S.F., Scimeca, J.A. \& Pariza, M.W. 1991. Mammary cancer prevention by conjugated dienoic derivative of linoleic acid. Cancer Res. 51:6118-6124.

Ip, C., Scimeca, J.A. \& Thompson, H. J. 1994. Conjugated linoleic acid. A powerful anticarcinogen from animal fat sources. Cancer 74(3):1050-1054.

Ip, C., Scimeca, J.A. \& Thompson, H. 1995. Effect of timing and duration of dietary conjugated linoleic acid on mammary cancer prevention. Nutr. Cancer 1995;24:241-247.

Katan, M.B., Zock, P.L. \& Mensink, R.P. 1995. Dietary oils, serum lipoproteins and coronary heart disease. Am. J. Clin. Nutr. 61:1368S-1373S.

Knekt, P., Järvinen, R., Seppänen, R., Pukkala, E. \& Aromaa, A. 1996. Intake of dairy products and the risk of breast cancer. Br. J. Cancer 22:520-527.

Kromhout, D., Menotti, A., Bloemberg, B., Aravanis, C., Blackburn, H., Buzina, R., Dontas, A. S., Fidanza, F., Giampaoli, S., Jansen, A. 1995. Dietary saturated and trans fatty acids and cholesterol and 25-year mortality from coronary heart disease: the Seven Countries Study. Prev. Med. 23(4):308-315.

Larsson SC, Bergkvist L \& Wolk A. 2005. High-fat dairy food and conjugated linoleic acid intakes in relation to colorectal cancer incidence in the Swedish Mammography Cohort. Am. J. Clin. Nutr. 82:894-900.

Levine GN, Keaney, J. F., Vita, J. A. 1995. Cholesterol Reduction in Cardiovascular Disease -- Clinical Benefits and Possible Mechanisms. N Engl. J. Med. 332:8:512-521.

Mennen, L.I., Lafay, L., Feskens, E.J.M., Novak, M., Lepinay, P. \& Balkau, B. 2000. Possible protective effect of bread and dairy products on the risk of the metabolic syndrome. Nutr. Res. 20:335-347.

Mensink RP, Zock PL, Kester ADM, Katan MB. Effects of dietary fatty acids and carbohydrates on the ratio of serum total to HDL cholesterol and on serum lipids and apolipoproteins: a meta-analysis of 60 controlled trials. Am J Clin Nutr 2003;77:1146-1155.

Merrill, A.H. Jr, Schmelz, E.M., Wang, E., Schroeder, J.J., Dillehay, D. L. \& Riley, R. T. 1995. Role of dietary sphingolipids and inhibitors of sphingolipid metabolism in cancer and other diseases. J. Nutr. 125(6 suppl):1677S-1682S. 
Mirmiran, P., Esmaillzadeh, A. \& Azizi, F. 2005. Dairy consumption and body mass index: an inverse relationship. Int J Obes 29(1):115-121.

Mozzaffarian, D., Rimm, E.B. \& Herrington, D.M. 2004. Dietary fats, carbohydrate, and progression of coronary atherosclerosis in postmenopausal women. Am. J. Clin. Nutr. 80:1175:1184.

Park, Y., Albright, K.J., Liu, W., Storkson, J.M., Cook, M.E. \& Pariza, M.W. 1997. Effect of conjugated linoleic acid on body composition in mice. Lipids 32;853-858.

Pereira, M.A., Jacobs, D.R., Van Horn, L., Slattery, M.L., Kartashov, A.I. \& Ludwig, D.S. 2002. Dairy consumption, obesity, and the insulin resistance syndrome in young adults - the Cardia study. J.A.M.A. 287:2081-2089.

Pietinen, P., Ascherio, A., Korhonen, P., Hartman, A.M., Willett, W.C., Albanes, D. \& Virtamo, J. 1997. Intake of fatty acids and risk of coronary heart disease in a cohort of Finnish men: The Alpha-Tocopherol, BetaCarotene Cancer Prevention Study. Am. J. Epidemiol. 145:876-87.

Planchon, P., Raux, H., Magnien, V., Ronco, G., Villa, P., Crépin, M. \& Brouty-Boyé, D. 1991. New stable butyrate derivatives alter proliferation and differentiation in human mammary cells. Int J Cancer 1991;48:443449.

Rajakangas, J., Basu, S., Salminen, I. \& Mutanen M. 2003. Adenoma growth stimulation by the trans-10, cis12 isomer of conjugated linoleic acid (CLA) is associated with changes in mucosal NF-kappaB and cyclin D1 protein levels in the Min mouse. Journal of Nutrition. 133(6):1943-8.

Rosell, M., Johansson, G., Berglund, L., Vessby, B., de Faire, U. \& Hellénius, M.-L. 2004. Associations between the intake of dairy fat, calcium and abdominal obesity. Int. J. Obes. Relat. Metab. Disord. 28:14271434.

Ruidavets, J.-B., Bongard, V., Simon, C., Dallongeville, J., Ducimetière, P., Arveiler, D., Amouyel, P., Bingham, A. \& Ferrieres, J. 2006. Independent contribution of dairy products and calcium intake to blood pressure variations at a population level. J. Hypertens. 24:671-681.

Salter, A.M., Mangiapane, E.H., Bennett, A.J., Bruce, J.S., Billett, M.A., Anderton, K., Marenah, C.B., Lawson, N. \& White, D.A. 1998. The effect of different dietary fatty acids on lipoprotein metabolism: concentration-depedent effects of diets enriched in oleic, myristic, palmitic and stearic acid. Br. J. Nutr. 79(2):195-202.

Shekelle, R.B., Shyrock, A.M., Paul, O., Lepper, M., Stamler, J., Liu, S. \& Raynor, W.J. 1981. Diet, serum cholesterol and death from coronary heart disease: The Western Electric Study. N. Engl. J. Med. 304:65-70.

Stamler, J., Wentworth, D. \& Neaton, J.D. 1986. Is relationship between serum cholesterol and risk of death ffrom coronary heart disease continuous and graded? Findings in 356222 primary screenees of the Multiple Risk Factor Intervention Trial (MRFIT). J.A.M.A. 256:2823-2828.

Tricon, S., Burdge, G.C., Williams, C.M., Calder, P.C. \& Yaqoob, P. 2005. The effects of conjugated linoleic acid on human helath-related outcomes. Proc. Nutr. Soc. 64;171-182.

Vesper, H., Schmelz, E.-M., Nikolova-Karakashian, M.N., Dillehay, D.L. \& Merrill, A.H. 1999. Sphingolipids in food and the emerging importance of sphingolipids to nutrition. J. Nutr. 129:1239-1250.

Voorrips, L.E., Brants, H.A., Kardinaal, A.F., Hiddink, G.J., van den Brandt, P.A. \& Goldbohm, R.A. 2002. Intake of conjugated linoleic acid, fat, and other fatty acids in relation to postmenopausal breast cancer: the Netherlands Cohort Study on Diet and Cancer. Am. J. Clin. Nutr. 76(4):873-82.

Warensjö, E., Jansson, J. H., Berglund, L., Boman, K., Ahrén, B., Weinehall, L., Lindahl, B., Hallmans, G. \& Vessby, B. 2004. Estimated intake of milk fat is negatively associated with cardiovascular risk factors and does not increase the risk of a first acute myocardial infarction. A prospective case-control study. Br. J. Nutr. 91:635-642.

Whigham, L. D., Watras A.C. \& Schoeller, D.A. 2007. Efficacy of conjugated linoleic acid for reducing fat mass: a meta-analysis in humans. Am. J. Clin. Nutr. 85:1203-1211.

Zemel, M.B., Shi, H., Greer, B., Dirienzo, D. \& Zemel, P.C. 2000. Regulation of adiposity by detary calcium. FASEB J. 14(9):1132-1138.

Zemel, M.B., Thompson, W., Milstead, A., Morris, K. \& Campbell, P. 2004. Calcium and dairy acceleration of weight and fat loss during energy restriction in obese adults. Obes. Res. 12:582-590.

Xu, J., Eilat-Adar, S., Loria, C., Goldbourt, U., Howard, B.V., Fabsitz, R.R., Zephier, E.M., Mattila, C. \& Lee, E.T. 2006. Dietary fat intake and risk of coronary heart disease: the Strong Heart Study. Am. J. Clin. Nutr.84;894-902.

Yanagi, S., Yamashita, M., Ogoshi, K. \& Imai, S. 1994. Comparative effects of milk, youghurt, butter and margarine on mammary tumorigenesis induced by 7,12-dimethylbenz[a]anthracene in rats. Cancer Detect. Prev. 18:415-420. 